\title{
IDENTIFIKASI MISKONSEPSI SISWA PADA MATERI SISTEM REPRODUKSI
}

\author{
Yusi Ardiyanti ${ }^{1}$ ), Marsah Rahmawati Utami ${ }^{2}$ ) \\ Program Studi Pendidikan Matematika, Fakultas Keguruan dan Ilmu Pendidikan, \\ Universitas Singaperbangsa Karawang \\ Jl. HS.Ronggo Waluyo, Telukjambe Timur, Kabupaten Karawang 41361 Indonesia \\ e-mail : yusi.ardiyanti@staff.unsika.ac.id,marsah.r.utami@gmail.com
}

\begin{abstract}
Abstrak
Pemahaman konsep biologi sangat diperlukan dalam pengintegrasian alam dan teknologi dalam kehidupan seharihari, jika pemahaman konsep sudah kuat, siswa dapat mengembangkan dan memahami konsep yang lebih tinggi. Namun terkadang siswa mempunyai pemahaman konsep yang berbeda dengan konsep yang diterima secara ilmiah dan hal tersebut akan menyebabkan miskonsepsi. Tujuan penelitian ini adalah untuk mengetahui ada tidaknya miskonsepsi pada siswa dan sub konsep apa yang paling banyak mengalami miskonsepsi pada materi sistem reproduksi. Untuk menghitung tingkat miskonsepsi metode Certainty of Response Index (CRI) dengan subyek penelitian adalah siswa kelas XI SMA 2 Cikampek. Data yang di dapat menunjukkan siswa mengalami miskonsepsi untuk beberapa sub konsep. Miskonsepsi tertinggi ada pada subkonsep menstruasi, yaitu sebesar 32,5\% sedangkan terendah ada pada subkonsep pembentukan gamet sebesar $10 \%$. Hal tersebut dikarenakan siswa menginterprtasikan sendiri pemahaman sebuah materi berdasarkan buku teks yang dibaca dan penjelasan dari guru.
\end{abstract}

Kata kunci : Miskonsepsi, Sistem Reproduksi.

\begin{abstract}
Understanding the concept of biology is necessary in the integration of nature and technology in everyday life, if the concept of understanding is strong, students can develop and understand higher concepts. But sometimes students have a different understanding of concepts with scientifically accepted concepts and that will lead to misconceptions. The purpose of this study is to determine whether there is misconception in students and sub-concept what most misconception in reproduction system material. To calculate the misconception level of the Certainty of Response Index (CRI) method with the subjects of the study were students of class XI SMA 2 Cikampek. The data can show students misconception for some sub-concepts. The highest misconceptions exist in the menstrual subconses, which is $32.5 \%$ while the lowest is in the $10 \%$ gamete formation subconsep. This is because students interpret their own understanding of a material based on a text book that is read and an explanation from the teacher.
\end{abstract}

Keywords: Misconception, Reproductive System.

\section{PENDAhULUAN}

Biologi merupakan salah satu mata pelajaran IPA dan mata pelajaran peminatan akademik pada Sekolah Menengah Atas berdasarkan kurikulum 2013. Pembelajaran biologi lebih menekankan pada pengalaman langsung supaya dapat dikembangkan sesuai dengan kompetensi siswa dalam memahami alam sekitar secara ilmiah. Pembelajaran biologi bertujuan membuat siswa mampu memahami konsep-konsep biologi, mam- pu mengaitkan satu konsep dengan konsep yang lain, dan mampu memecahkan masalah dalam kehidupan sehari-hari. Dahar (2011) mengatakan bahwa konsep merupakan hal yang sangat penting, karena konsep merupakan landasan untuk berpikir.

Kara dan Yesilyurt (2008) menyatakan bahwa pemahaman konsep biologi sangat diperlukan dalam pengintegrasian alam dan teknologi dalam kehidupan sehari-hari. Selain itu, pema- 
haman konsep dapat membantu siswa dalam mendeskripsikan dan menghubungkan antar konsep umtuk menjelaskan peristiwa-peristiwa alam yang terjadi dalam kehidupan sehari-hari (Winahyu, 2007).

Pendapat di atas jelas bahwa dalam pembelajaran biologi sangat di perlukan pemahaman konsep. Jika pemahaman konsep sudah kuat, siswa dapat mengembangkan dan memahami konsep yang lebih tinggi. Konsep yang satu dengan konsep yang lain saling berhubungan sehingga pengetahuan awal sangat penting karena berperan untuk konsep selanjutnya. Sebagai contoh pada materi klasifikasi hewan, siswa sering menganggap semua hewan yang hidup di air adalah ikan dan hewan yang bisa terbang adalah burung. Pada konsep sebenarnya tidak semua hewan air adalah ikan (pisces), contohnya paus yang merupakan mamalia dan tidak semua hewan yang bisa terbang adalah burung (aves), contohnya kelelawar yang juga merupakan kelas dari mamalia (Hidayati, 2013:1-2). Contoh tersebut menunjukkan bahwa siswa seringkali mempunyai pemahaman konsep yang berbeda dengan konsep yang diterima secara ilmiah dan hal tersebut akan menyebabkan miskonsepsi (Tekkaya et al, 2001; Ekici et al, 2007; Kose, 2008). Kesalahan ini biasanya ditunjukkan pada saat menjelaskan suatu konsep dengan menggunakan bahasa sendiri (Kustiyah, 2007). Miskonsepsi siswa muncul paling banyak bukan pada saat proses belajar mengajar berlangsung namun sebelum proses belajar mengajar dimulai.

Faktor-faktor penyebab miskonsepsi dapat berasal dari siswa, guru, buku teks, konteks dan metode mengajar (Suparno, 2005). hal itu sejalan dengan yang diungkapkan oleh Ibrahim (2012) bahwa miskonsepsi bersumber dari kemampuan berfikir siswa itu sendiri, pengalaman siswa, proses pembelajaran, penjelasan dari guru dan buku pelajaran. Namun Chaniarosi (2014) mengungkapkan bahwa guru juga memiliki andil yang cukup besar terhadap miskonsepsi siswa, hal ini disebabkan karena salah satu terjadinya miskonsepsi pada siswa adalah guru yang memiliki miskonsepsi terhadap mata pelajaran itu sendiri. berdasarkan pernyataan tersebut dapat kita katakan bahwa jika guru salah dalam memahami dan memberi penjelasan mengenai konsep pem- belajaran, maka siswa juga akan menerima konsep yang salah.

Katu (Asma \& Masril, 2002), mengungkapkan bahwa untuk mendeteksi miskonsepsi dapat dilakukan dengan cara sebagai berikut, diantaranya: Memberi tes diagnostik pada awal atau pada setiap akhir pembahasan dan bisa dilakukan dengan berbagai cara, misalnya memberikan tugas-tugas terstruktur misalnya tugas mandiri atau kelompok sebagai tugas akhir pengajaran atau tugas pekerjaan rumah; memberikan pertanyaan terbuka, pertanyaan terbalik, atau pertanyaan yang kaya akan konteks; mengoreksi/membimbing langkah-langkah yang digunakan siswa dalam menyelesaikan soal-soal esai; mencoba mengajukan pertanyaan-pertanyaan terbuka secara lisan kepada siswa; bisa juga dengan wawancara, bisa sifat nya tertutup atau wawancara terbuka; tahap terakhir adalah dengan penanggulangan Miskonsepsi.

Pada penelitian ini, penulis tertarik membahas topik tentang sistem reproduksi manusia yang merupakan salah satu konsep dalam biologi yang memerlukan tingkat pemahaman konsep tinggi serta sangat erat kaitannya dengan kehidupan sehari-hari. Materi ini mempunyai subkonsep-subkonsep yang saling berkaitan yang memungkinkan siswa untuk memahaminya diperlukan pemahaman awal terhadap materi tersebut, jika pemahaman awal siswa tidak kuat, maka untuk memahami sub konsep berikutnya akan rentan mengalami miskonsepsi.

Berdasarkan pemaparan di atas, maka miskonsepsi pada siswa cukup berpengaruh terhadap hasil belajar hal ini dikarenakan miskonsepsi dapat menghambat pemahaman dalam konsep biologi, sebab materi dalam biologi saling berkaitan erat dan merupakan kunci untuk memahami konsep lain, sehingga miskonsepsi pada satu konsep dapat mengakibatkan miskonsepsi pada konsep lain (Tekkaya, 2002). Sehingga tujuan penelitian ini adalah untuk mengetahui ada tidaknya miskonsepsi pada siswa dan sub konsep apa yang paling banyak mengalami miskonsepsi pada materi sistem reproduksi.

\section{METODE PENELITIAN}

Penelitian ini merupakan penelitian deskriptif, karena bertujuan menyelidiki responden berdasarkan pemahaman konsep (Nasution, 
2012). Subjek penelitian adalah salah satu kelas XI dari seluruh siswa kelas XI SMAN 2 Cikampek. Untuk mengetahui tingkat miskonsepsi siswa maka digunakan metode Certainty of Response Index (CRI). Data yang diperoleh dari hasil penelitian yaitu data kuantitatif berupa data hasil tes disertai form CRI. Ranvangan penelitian terdiri dari tiga tahap, yaitu:

Tahap persiapan, membuat intrumen penelitian berupa soal pilihan ganda tentang materi sistem reproduksi yang di lengkapi dengan nilai CRI. Kriteria soal bisa di lihat pada tabel 1 .

Tabel 1.

Kriteria soal CRI dengan materi sistem reproduksi

\begin{tabular}{lc}
\hline \multicolumn{1}{c}{ Sub konsep } & Jumlah soal \\
\hline Struktur dan fungsi organ reproduksi manusia & 4 \\
Pembentukan gamet & 4 \\
Ovulasi & 4 \\
Menstruasi & 4 \\
Fertilisasi, gestasi, persalinan, dan laktasi & 4 \\
Kelainan organ reproduksi & 4 \\
Jumlah & 24 \\
\hline \hline
\end{tabular}

Tahap pelaksanaan, menentukan jumlah siswa yang akan di jadikan subjek penelitian sesuai dengan yang disarankan oleh wakil kepala sekolah bagian kurikulum dan meminta ijin kepada guru biologi yang mengajar pada kelas tersebut. Melakukan tes CRI dan selanjutnya menghitung nilai CRI yang diperoleh dari jawaban siswa.

Tahap langkah analisis data, yang dilakukan dalam penelitian ini yaitu: 1) ditentukan nilai CRI berdasarkan pada kelas yang disusun, 2) ditentukan kategori tingkat pemahaman berdasarkan pilihan jawaban, dan nilai CRI, 3) melakukan analisis jawaban siswa untuk membedakan antara tahu konsp (TK), miskonsepsi (M) dan tidak tahu konsep (TTK), 4) dilakukan perhitungan persentase penilaian untuk soal pilihan ganda, 5) penghitungan persentase dihitung dengan menggunakan rumus dan kemudian disesuaikan hasil ratarata CRI yang di peroleh dengan tabel 2.
Tabel 2.

Kriteria Tahu Konsep, Miskonsepsi dan Tidak Tahu Konsep

\begin{tabular}{lll}
\hline \hline $\begin{array}{l}\text { Kriteria } \\
\text { jawaban }\end{array}$ & CRI rendah $(<2,5)$ & CRI tinggi $(>2,5)$ \\
\hline Benar & $\begin{array}{l}\text { Tidak tahu konsep } \\
\text { (menebak) }\end{array}$ & $\begin{array}{l}\text { Menguasai konsep } \\
\text { dengan baik }\end{array}$ \\
Salah & $\begin{array}{l}\text { Tidak tahu konsep } \\
\text { (menebak) }\end{array}$ & Miskonsepsi \\
\hline \hline
\end{tabular}

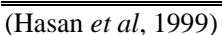

\section{III.HASIL DAN PEMBAHASAN}

Penelitian ini dilakukan pada bulan mei 2017 pada siswa kelas XI IPA 2 sebanyak 44 siswa, namun yang hadir pada hari itu ada 40 siswa. Hasil dari tes CRI menunjukkan bahwa siswa terindikasi mengalami miskonsepsi pada sub konsep -sub konsep tertentu, sub konsep-sub konsep yang mengalami miskonsepsi dapat di lihat pada tebel 3 .

Tabel 3

Presentasi miskonsepsi, tidak tahu konsep dan tahu konsep siswa SMA pada materi sistem reproduksi

\begin{tabular}{lcccc}
\hline \multirow{2}{*}{ Sub Konsep } & \multicolumn{3}{c}{ Persentasi } & \multirow{2}{*}{ Total } \\
\cline { 2 - 4 } & TK & M & TTK & \\
\hline Struktur dan fungsi organ & 87,5 & 0 & 12,5 & 100 \\
reproduksi manusia & 77,5 & 10 & 12,5 & 100 \\
Pembentukan gamet & 57,5 & 20 & 22,5 & 100 \\
Ovulasi & 45 & 32,5 & 47,5 & 100 \\
Menstruasi & 55 & 17,5 & 27,5 & 100 \\
Fertilisasi, gestasi, & 90 & 0 & 10 & 100 \\
persalinan, dan laktasi & Kelainan organ reproduksi & \multicolumn{4}{c}{} \\
\hline \hline TK: Tahu Konsep, M: Miskonsepsi, TTK: Tidak tahu Konsep
\end{tabular}

Berdasarkan tabel 3 di dapat hasil bahwa hampir seluruh siswa mengalami miskonsepsi pada setiap sub konsep, hanya sub konsep Struktur dan fungsi organ reproduksi manusia serta kelainan organ reproduki saja yang tidak mengalami miskonsepsi. Sub konsep selebihnya siswa mengalami miskonsepsi. Miskonsepsi tertinggi ada pada subkonsep menstruasi, yaitu sebesar $32,5 \%$ sedangkan terendah ada pada subkonsep pembentukan gamet sebesar 10\%. Sedangkan sub konsep yang mengalami miskonsepsi sebesar $17,5 \%$ yaitu pada sub konsep Fertilisasi, gestasi, persalinan, 
dan laktasi. Sedangkan untuk sub konsep Ovulasi mengalami miskonsepsi sebesar $20 \%$.

Berdasarkan tes CRI, perbandingan persentase miskonsespi.

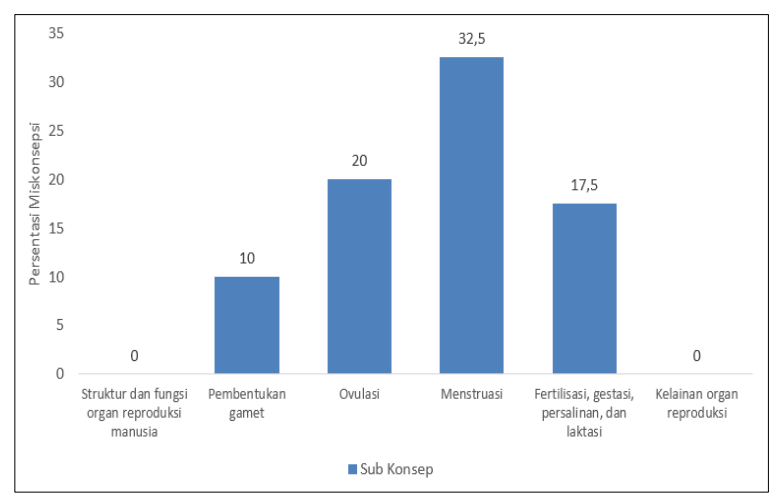

Gambar I. Persentase Siswa yang Mengalami Msikonsepsi pada Subkonsep-Sub konsep Materi Sistem Reproduksi

Gambar I menunjukkan bahwa 2 sub konsep tidak mengalami miskonsepsi, hal ini di karenakan untuk sub konsep struktur dan fungsi organ reproduksi manusia, sebagian besar siswa sudah mengetahui alat-alat reproduksi manusia, walaupun masih ada sebagian siswa yang hanya tahu bahwa alat reproduksi pada perempuan adalah vagina dan pada laki-laki adalah penis dan testis. Menurut data yang di dapat pemahaman konsep yang salah dari siswa tentang alat-alat reproduksi tersebut itu menunjukkan ketidaktahuan siswa dan bukan berada pada tahap miskonsepsi.

Sub konsep kelainan reproduksi juga tidak mengalami miskonsepsi pada pemahaman siswa, berdasarkan data yang di dapat, karena siswa kecenderungan sudah mengetahui kelainan-kelainan organ reproduksi, terutama untuk penyakit-penyakit yang di akibatkan karena alat-alat reproduksi yang tidak sehat, tidak sempurna, dan kesalahan pada prosesnya. Sebagai contoh soal yang diberikan adalah tentang kelainan/ penyakit pada sistem reproduksi, misalnyaadalah AIDS. Siswa menunjukkan pemahaman yang cukup baik tentang AIDS, penyebab, proses terjadi sampai bagaimana penanggulangannya.

Menstruasi adalah sub konsep yang paling tinggi mengalami miskonsepsi, yaitu sebesar 32,5. Hal ini menunjukkan masih melekatnya pemahaman siswa tentang mitos-mitos seputar menstruasi. Diantaranya adalah mitos bahwa ke- tika siswa perempuan yang terlalu banyak minum es bisa menyebabkan berhentinya menstruasi, atau pemahaman mereka tentang menopouse yang menyebutkan bahwa menstruasi akan berhenti ketika seorang wanita sudah habis ovariumnya. Padahal pada konsep yang sebenarnya menopouse akan terjadi bilamana folikel kurang merespon hormon FSH dan LH yang menyebabkan terhentinya ovulasi (Ganong, 2008). Berdasarkan penelitian Chaniarosi (2014) disebutkan pula bahwa guru juga mengalami miskonsepsi pada sub konsep ini dengan menyebutkan bahwa menopouse terjadi karena ovarium tidak menghasilkan sel telur akibat hormon progresteron menurun. Hal tersebut menunjukkan bahwa siswa mengalami miskonsepsi bisa diakibatkan karena kesalahan mereka dalam menginterpretasikan pemahaman yang disampaikan oleh guru, namun hal ini tidak bisa digeneralisasikan mengingat guru dan siswa yang menjadi subjek penelitian berada pada tempat yang berbeda. Naum hal ini bisa saja di jadikan asumsi untuk penelitian lebih lanjut.

Sub konsep yang paling rendah mengalami miskonsepsi adalah tentang pembentukan gamet, yaitu sebesar 10. Sebagian besar siswa menunjukkan pengetahuannya tentang proses pembentukan gamet. Walaupun ada sebagian siswa yang merasa itu bersipat hapalan, jadi dia hapal bagimana proses pembentukan gamet tapi tidak paham maksud dari proses tersebut. Seperti halnya pada saat proses meiosis bahwa sel akan terus membelah karena memang proses meiosis seperti itu.

Fertilisasi, gestasi, persalinan dan laktasi adalah sub konsep terendah kedua yang mengalami miskonsepsi, yaitu sebesar 17,5. Salah satu miskonsepsi yang dialami siswa adalah masalah metode kontrasepsi, siswa banyak menyebutkan seorang ibu yang sudah melahirkan ketika tidak mau lagi mempunyai anak maka bisa memasang alat kontrasepsi berupa spiral yang ditanam di dalam rahim sehingga tidak mungkin lagi seorang ibu mempunyai anak. Menurut konsep yang benar adalah ketika seorang ibu memutuskan untuk tidak lagi memilki anak, maka metode yang diambil adalah tubektomi yaitu pemotongan tuba palofii kemudian di ikat sehingga kemungkinan besar sperma tidak bisa lagi bertemu dengan ovum (Ulrich, 1996). 
Contoh lain ditunjukkan dengan sub konsep tentang metode penanganan kehamilan. Ketika seorang ibu dinyatakan positif hamil, maka langkah pertama yang dilakukan adalah dengan tes urin. Menurut siswa karena hormon LH dan FSH yang biasanya ada pada siklus bulanan seorang wanita terpapar pada urin, maka dapat disimpulkan bahwa ibu hamil dapat di tes melalui urinnya tersebut. Menurut konep bahwa ketika seorang wanita hamil (pada saat implantasi sel telur pada dinding rahim) maka tubuh akan banyak menghasilkan hormon HCG (hormon chorionc gonadotropin) dan hormon ini dapat terdeteksi 14 hari setelah konsepsi ( Ulrich, 1996; Baety, 2011).

Sub konsep terakhir yang mengalami miskonsepsi adalah mengenai ovulasi, yaitu sebesar 20. Sub konsep inipun kecenderungan siswa banyak yang mengetahui apa ovulasi dan bagaimana prosesnya, namun sekali lagi kecenderungan banyak siswa yang hanya apal bagaimana proses namun tidak paham apa maknanya. Kecenderungan siswa memahami bahwa terjadinya ovulasi itu disebabkan pergiliran keluarnya hormon. Sebagai contoh, bahwa ovulasi terjadi karena hormon FSH dikeluarkan oleh tubuh. Sebetulnya FSH (folikel stimulating hormon)berfungsi merangsang perkembangan folikel telur dan selsel folikel yang sedang tumbuh tersebut akan mensekresikan estrogen, sedangkan hormon yang merangsang terjadinya ovulasi adalah LH (luitinezing Hormon) (Ulrich, 1996; Campbell, 2003).

Berdasarkan data penelitian, kecenderungan siswa mengalami miskonsepsi karena kesalahan siswa dalam menginterpretasikan pemahamannya tentang materi sistem reproduksi berdasar pada penjelasan guru dan buku teks yang di baca. Buku teks menjadi sumber acuan yang dipahami dapat menyebabkan siswa mengalami miskonsepsi (Kustiyah, 2007) karena tidak dipungkiri banyak penelitian juga yang menyebutkan bahwa buku teks atau konsep yang ada di dalamnya bisa menyebabkan miskonsepsi.

Berdasarkan data-data di atas, maka dapat di sarankan bagaimana tidakan prefentif dan kuratif seperti berikut yang diadposi dari Asma \& Masril (2002) berikut ini: berikan pertanyaan apersepsi untun menarik minat dan motivasi belajar, selalu memberikan tes diagnostik pada awal atau akhir pembelajaran, usahakan selalu menu- gaskan untuk pekerjaan rumah dan memeriksa jawabannya, menggunakan banyak konteks untuk konsep-konsep dalam pembelajaran, sering latih mereka untuk bisa tes lisan agar pemahaman yang mereka pikirkan bisa kita deteksi sedini mungkin apakah salah atau tidak, hingga akhirnya kita bisa mengetahui adanya miskonsepsi atau tidak terhadap siswa.

Tindakan kuratif, ketika siswa menglami miskonsepsi adalah, dengan melakukan langkahlangkah persuasif, seperti: mencoba sesering mungkin membuat pertanyaan-pertanyaan yang sifat nya lisan, selalu menyimpulkan akhir bahasan setiap konsep, dan harus muali di lakukan pembiasaan-pembiasan untuk mencari ragam konteks untuk mejelaskan sebuah konsep dan lain sebagainya. Sehingga di mungkinkan dengan pembiasaan siswa dapat mulai bisa membuka diri untuk menyampaikan pemahaman yang ada dalam pikirannya sehingga dengan mudah bagi seorang guru mengetahui siswa tersebut mengalami miskonsepsi atau tidak.

\section{IV.KESIMPULAN}

Dari penelitian menunjukkan, bahwa siswa masih mengalami miskonsepsi pada materimateri yang membutuhkan pemahaman tinggi dan mempunyai konsep saling keterkaitan. Penyebab miskonsepsi siswa ini lebih dikarenakan siswa menginterpretasikan dan menimpulkan sendiri suato konsep berdasar dari pemaparan guru dan buku teks, tanpa mengungkapkan pemahamannya tersebut pada guru, sehingga dimungkinkan miskonsepsi ini terus berlanjut. Penelitian selanjutnya tentang miskonsepsi diharapkan dapat mengungkap lebih jauh permasalahan mengenai kenapa peneyebab siswa mengalami miskonsepsi dan bagaimana menganggulanginya, sehingga diharapkan kualitas pendidikan lebih baik.

\section{DAFTAR PUSTAKA}

Baety, A.N. (2011). Biologi Reproduksi kehamilan dan Persalinan. Yogyakarta: Graha Ilmu.

Campbell, N.A., Jane, B.R., \& Lawrence, G.M. (2003). Biologi edisi kelima jilid 3. Jakarta; Erlangga. 
Chaniarosi, L. F. (2014). Identifikasi Miskonsepsi Guru Biologi SMA Kelas XII IPA pada Konsep Reproduksi Manusia. Jurnal EduBio Tropika. Vol 2, no 2. 167250 .

Drews, Ulrich. (1996). Atlas Embriologi. Jakarta: Hipokrates.

Ekici, F., ekici, E., \& Aydin. (2007). Utility of Concept Cartoons in Diagnosing and Over coming Misconception related to Photosynthesis. International Journal of Environmental \&Science Education, 2(4):111-124

Ganong,W.F. (2008). Fisiologi Kedokteran. Jakarta: EGC.

Kara. Y., Yesilyurt. (2008). Comparing the Impact Tutorial And Edutainment Software Program on Student' Achievment, Misconception, and Attitudes toward
Biologi. Journal Science Education and Technology, 17: 32-41.

Kose, S. (2008). Diagonsing Student Misconseptions: Using Drawing as a Research method. World Applied Sciences Journal, ISSN 18184952, Vol 3. (2)/pp-283-293.

Kustiyah. (2007). Miskonsepsi Difusi dan Osmosis pada Siswa MAN Model Palangkaraya. Jurnal Ilmiah Guru kanderang Tingan, 5:24-37.

Suparno, Paul. (2005). Miskonsepsi dan Perubahan Konsep dalam Pendidikan Fisika. PT Grasindo: Jakarta

Tekkaya, C., Ozkan, S., Asci, Z. (2001). Student's misconceptions about Respiration:across age study.Egitim ve Bikim 120 (26), 29-36. 